\title{
58. On Kaersutite from Morotu, Sakhalin
}

\author{
By Kenzo YAGI \\ Institute of Earth Sciences, Tohoku University, Sendai, Japan \\ (Comm. by S. Kôzu, M.J.A., June 12, 1953)
}

\section{Introduction}

In the Morotu district on the western coast of South Sakhalin various kinds of alkalic rocks are found as sheets, laccoliths, and dikes in the Tertiary formations (Iwao, 1939, p. 155; Yagi, 1953). The rocks vary from dolerite through monzonite to syenite. Of these dolerite is most abundant, constituting the greater part of most of the intrusive bodies, while monzonite and syenite occur either in the central parts of the bodies, or as irregular veinlets in the doleritic parts. In some of the monzonites or syenites, amphiboles occur as important constituent minerals, and range from barkevikite through hastingsite to arfvedsonite, among which deep brown hornblende with strong pleochroism attracted special attention. At first it was taken for barkevikite. However, its chemical analysis showed an unusually high titanium content, and because of this, coupled with its optical properties, the hornblende under question was designated as kaersutite, a rather rare variety of basaltic hornblende high in titanium content. In the present note a brief description of the kaersutite will be given. The petrochemical study of the alkalic rocks of the Morotu district in general will be given in another paper.

\section{Petrographic Description of the Host Rock}

A thick sheet found in the cut at Tyaki, about $10 \mathrm{~km}$ southeast of Morotu, is composed mostly of dolerite, which shows onion structure accompanied by cuboidal joints. Numerous pea-shaped aggregates of early formed diopsidic augite and labradorite are found in the dolerite, and often fall out from the decomposed dolerite, owing to their greater resistance to weathering. Irregular veins or schlieren of monzonite, $50 \mathrm{~cm}$ up to $5 \mathrm{~m}$ thick, are sporadically distributed in the dolerite. The monzonite is coarse-grained, and remains quite fresh in contrast to the easily decomposed surrounding dolerite. The monzonite has abundant miarolithic cavities, and is chiefly composed of tabular feldspar, biotite flakes, and prismatic hornblende and augite. Microscopically the rock shows hypidiomor- 
phic granular texture, and the main constituent minerals are microperthite, plagioclase, kaersutite, titanbiotite, titaniferous sodaaugite, and aegirinaugite (Fig. 1). Minor components are ilmenite,

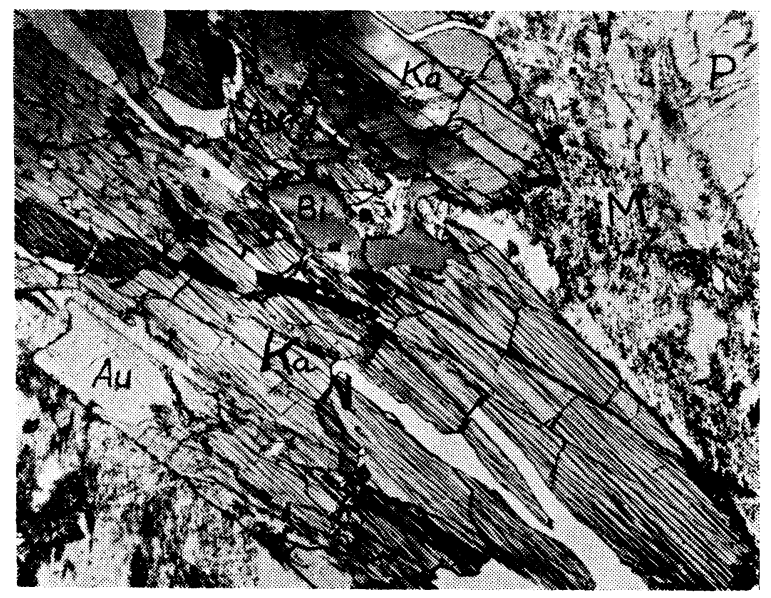

P....Plagioclase core
Au... Soda-augite
Ka... Kaersutite

M... Microperthite shell

Bi... Titanbiotite $(\times 41)$

Fig. 1. Photomicrograph of the monzonite No. 1305 G, Tyaki, Morotu, showing zoned feldspar and parallel growth of mafic minerals

magnetite, analcite, apatite, and sphene. Feldspar shows interesting zonal structure with a core of plagioclase, a shell of microperthite, and a rim of albite. Plagioclase in the core is twinned on the albite law. $n_{2}=1.545,2 V(-)=69^{\circ}, 73^{\circ}, 80^{\circ}$, and $\mathrm{An}_{25}$ in composition. Outer shell of microperthite is twinned on the Carlsbad law, and has sporadic patches of anorthoclase. The outermost thin rim, $0.01-0.1 \mathrm{~mm}$ in width, is clear albite, twinned on the albite law. The boundaries between plagioclase, microperthite, and albite are always quite sharp and linear, but there is no zoning in the plagioclase itself. Titaniferous soda-augite occurs in stout prismatic crystals, $0.3-3.0 \mathrm{~mm}$ in size, and sometimes shows typical hour glass structure. It is frequently mantled by thin layer of aegirinaugite, the boundary being very gradual. Titanbiotite is very abundant, and occurs in tabular crystals less than $2 \mathrm{~mm}$ in size. Iron ores occur either in massive crystals or in skeletal forms, usually less than $0.5 \mathrm{~mm}$, and are sometimes mantled by titanbiotite. It is notable that apatite shows striking development, attaining sometimes 2 to $3 \mathrm{~mm}$ in length. Analcite and thomsonite are sporadically met with, though the rock is free from any alteration. Kaersutite 
will be described in detail in the next section. Chemical composition of the monzonite No. $1305 \mathrm{G}$, collected at this sheet of Tyaki is given in Table $\mathrm{I}$. It is characterized by high content of alkalis, especially of soda, resulting in the formation of nepheline molecule in norm, which is represented by the analcite in the mose. High titanium content is also significant, and is in agreement with the abundance of various titaniferous mafic minerals.

\section{Microscopical Observation of the Kaersutite}

The kaersutite under question occurs usually in prismatic crystals usually $0.5-3.0 \mathrm{~mm}$, and rarely 10

Table I

Chemical composition of the monzonite No. $1305 \mathrm{G}$

\begin{tabular}{|c|c|c|c|}
\hline \multicolumn{2}{|c|}{ Wt. \% } & \multicolumn{2}{|c|}{ Norm } \\
\hline $\mathrm{SiO}_{2}$ & 58.21 & Or & 16.68 \\
\hline $\mathrm{TiO}_{2}$ & 2.08 & $\mathrm{Ab}$ & 56.59 \\
\hline $\mathrm{Al}_{2} \mathrm{O}_{3}$ & 18.16 & An & 9.73 \\
\hline $\mathrm{Fe}_{3} \mathrm{O}_{3}$ & 1.99 & $\mathrm{Ne}$ & 1.42 \\
\hline $\mathrm{FeO}$ & 3.30 & Wo & 2.67 \\
\hline $\mathrm{MnO}$ & 0.07 & Di $\operatorname{En}$ & 1.90 \\
\hline $\mathrm{MgO}$ & 1.76 & IFs & 0.53 \\
\hline $\mathrm{CaO}$ & 3.41 & Fo & 1.75 \\
\hline $\mathrm{Na}_{2} \mathrm{O}$ & 6.99 & $01\{\mathrm{Fa}$ & 0.41 \\
\hline $\mathrm{K}_{2} \mathrm{O}$ & 2.77 & Mt & 3.02 \\
\hline $\mathrm{H}_{2} \mathrm{O}^{+}$ & 1.11 & Il & 3.95 \\
\hline $\mathrm{H}_{2} \mathrm{O}^{-}$ & 0.48 & Ap & 0.34 \\
\hline $\mathrm{P}_{2} \mathrm{O}_{5}$ & 0.11 & & \\
\hline Total & 100.44 & Analyst & K. Yagi \\
\hline
\end{tabular}
$\mathrm{mm}$ in length, bounded by the forms (100), (010) with less prominent basal pinacoid. Cleavages parallel to (110) is perfect, and the twinning on (100) is common. Besides inclusions of apatite, magnetite or ilmenite, the crystals include not rarely feather-like inclusions of light grey color arranged diagonally in parallel rows. They have definite orientation relative to the cleavage of the host crystals, but their extremely minute size made the identification impossible. Optical properties of the kaersutite are as follows:

$n_{1}$ on $(110)=1.680, \quad n_{2}$ on $(110)=1.703$.

Extinction angle c $\wedge Z=16^{\circ}-19^{\circ}$.

Optic angle $2 V(-)=77^{\circ}-79^{\circ}$ (in the core) $\rightarrow$

Pleochroism, very strong:

$73^{\circ}$ (in the margin).

$X$... brownish yellow or straw yellow.

$Y$... reddish brown.

$Z$... deep chestnut brown with violet tinge.

Absorption : $\quad Z>Y>X$.

Zonal structure is rarely observed. Parallel growth with other mafic minerals is worthy of mention (Fig. 2). The order of arrangement from the core to the margin is usually as follows :

Kaersutite $\rightarrow$ titaniferous augite $\rightarrow$ titanbiotite, or

Kaersutite $\rightarrow$ titanbiotite $\rightarrow$ titaniferous augite.

In some cases they show much more complicated manner of intergrowth. Always b- and c-axes are in common in the participating crystals, and their boundaries are sharp and irregular. There- 


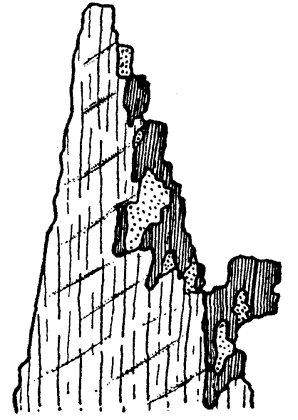

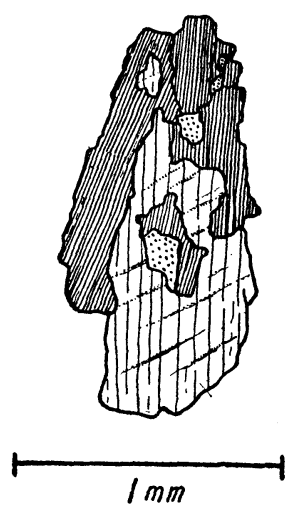

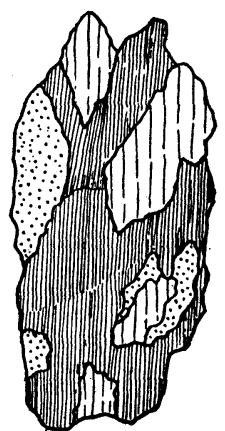

Stippled....Soda-augite

Coarsely hatched... Kaersutite
Finely hatched...Titanbiotite (All same magnification)

Fig. 2. Modes of parallel growth of mafic minerals

fore the kaersutite seems to be always earlier than other mafic minerals in the crystallization course. Magmatic resorption or formation of opacite margin, so common in some kaersutite, is entirely absent in the present case.

Quite similar kaersutite is found also in some syenites or monzonites from other localities of the Morotu district.

\section{Chemical Composition of the Kaersutite}

In order to get sample for chemical analysis, finely crushed fragments of the monzonite No. $1305 \mathrm{G}$ were divided into felsic and mafic fractions by the use of Thoulet's solution of specific gravity about 3.0, and then the mafic fraction was stirred vigorously by a glass rod in a beaker filled with water. Titanbiotite flakes suspended in the upper part, while kaersutite and augite grains settled on the bottom, and therefore, the former was separated from the latter by decantation. The mixture of kaersutite and augite was examined under the binocular microscope and the kaersutite grains were picked up by hand. Difference in color, cleavage, and shape made this method fairly accurate, though it was tedious work.

During the chemical analysis it was noticed that the usual fusion with alkali carbonates failed to render all the material completely soluble in the hydrochloric acid, and therefore the fusion was repeated. Impurities in the silica remaining after the treatment by hydrofluoric acid were unusually high, and pale brown in color. They were probably for the most part titanium oxide.

The chemical composition of kaersutite and its atomic propor- 
tion are given in Table II. The high $\mathrm{TiO}_{2}$ content is a significant feature. In the calculation of the chemical formula, the sum of $\mathrm{Si}+\mathrm{Al}$ in the atom group is less than 8 , when we take $\mathrm{O}+\mathrm{OH}=\mathbf{2 4}$, and therefore there should be replacement of Si-Ti in this kaersutite. Thus it is expressed as follows:

$$
\mathrm{OH}_{1.9}(\mathrm{Ca}, \mathrm{Na}, \mathrm{K})_{2.8}\left(\mathrm{Fe}^{\prime \prime}, \mathrm{Fe}^{\prime \prime \prime}, \mathrm{Mn}, \mathrm{Mg}, \mathrm{Al}\right)_{4.8}(\mathrm{Si}, \mathrm{Ti}, \mathrm{Al})_{8} \mathrm{O}_{22} \text {. }
$$

This is in agreement with Warren's general formula for hornblende;

$(\mathrm{OH}, \mathrm{F})_{2}(\mathrm{Ca}, \mathrm{Na}, \mathrm{K}, \mathrm{Mn})_{2-3}(\mathrm{Mg}, \mathrm{Fe}, \mathrm{Ti}, \mathrm{Mn}, \mathrm{Al})_{5}(\mathrm{Si}, \mathrm{Al})_{8} \mathrm{O}_{22}$ (Warren, 1930, p. 516).

Table II

Chemical composition of kaersutites from various localities of the world

\begin{tabular}{|c|c|c|c|c|c|c|c|c|c|}
\hline & $(1)$ & $(2)$ & $(3)$ & (4) & $(5)$ & (6) & $(7)$ & \multicolumn{2}{|c|}{ (la) } \\
\hline $\mathrm{SiO}_{2}$ & 40.73 & 39.78 & 38.30 & 39.20 & 39.50 & 40.85 & 41.46 & $\mathrm{Si}$ & 604 \\
\hline $\mathrm{TiO}_{2}$ & 8.47 & 7.00 & 6.02 & 6.53 & 10.33 & 8.47 & 5.70 & $\mathrm{Ti}$ & 94 \\
\hline $\mathrm{Al}_{2} \mathrm{O}_{3}$ & 10.62 & 14.13 & 12.87 & 13.87 & 11.12 & 9.89 & 14.24 & $\mathrm{Al}$ & 185 \\
\hline $\mathrm{Fe}_{2} \mathrm{O}_{3}$ & 1.39 & 4.61 & 7.98 & 4.08 & 0.06 & 8.85 & 3.32 & $\mathrm{Fe}^{\prime \prime \prime}$ & 16 \\
\hline $\mathrm{FeO}$ & 11.91 & 7.31 & 6.96 & 7.33 & 9.44 & 3.96 & 5.70 & $\mathrm{Fe}^{\prime \prime}$ & 147 \\
\hline $\mathrm{MnO}$ & 0.25 & 0.12 & 0.12 & 0.11 & 0.10 & 0.12 & 0.08 & $\mathrm{Mn}$ & 4 \\
\hline $\mathrm{MgO}$ & 10.46 & 11.01 & 11.79 & 11.96 & 12.90 & 12.47 & 13.68 & $\mathrm{Mg}$ & 233 \\
\hline $\mathrm{CaO}$ & 10.40 & 10.75 & 10.47 & 12.37 & 10.91 & 12.16 & 11.62 & $\mathrm{Ca}$ & 166 \\
\hline $\mathrm{Na}_{2} \mathrm{O}$ & 2.92 & 2.57 & 3.11 & 1.99 & 3.82 & 2.01 & 2.29 & $\mathrm{Na}$ & 84 \\
\hline $\mathrm{K}_{2} \mathrm{O}$ & 1.33 & 1.58 & 1.30 & 1.45 & 1.43 & 0.63 & 1.72 & $\mathrm{~K}$ & 25 \\
\hline $\mathrm{H}_{2} \mathrm{O}^{+}$ & 1.97 & 0.37 & 1.10 & 0.87 & 0.59 & 0.19 & 0.12 & $\mathrm{OH}$ & 194 \\
\hline $\mathrm{H}_{2} \mathrm{O}^{-}$ & 0.23 & 0.22 & 0.26 & 0.27 & - & - & - & $\mathrm{O}$ & 2206 \\
\hline \multirow[t]{2}{*}{$\mathbf{F}$} & - & - & 0.05 & - & - & 0.28 & 0.42 & & \\
\hline & 100.68 & 99.45 & 100.33 & 100.03 & 100.20 & $99.98^{*}$ & 100.35 & & \\
\hline Less $\mathrm{O}=\mathrm{F}$ & - & - & 0.02 & - & - & 0.12 & 0.18 & & \\
\hline Total & 100.68 & 99.45 & 100.31 & 100.03 & 100.20 & 99.86 & 100.17 & & \\
\hline
\end{tabular}

(1) Tyaki, Morotu. Anal. K. Yagi.

(2) Tikaisi, Dogo Island, Japan. Anal. Teshima; Tomita (1934, p. 1).

(3) Yohodo, Korea. Anal. Kawano; Kawano (1934, p. 127).

(4) Uturyo Island, Korea. Anal. Usizima; Harumoto (1933, p. 100).

(5) Kaersut, Greenland. Anal. Gossner ; Gossner and Spielberger (1930, p. 120).

(6) Monte Rosso, Linosa, Italy. Anal. Washington; Washington and Wright (1908, p. 192).

(7) Boulder Dam, Arizona, U.S.A. Anal. Gonyer ; Campbell and Schenk (1950, p. 684).

(la) Atomic ratio of kaersutite from Morotu, when $\mathrm{OH}+\mathrm{O}=2400$.

\section{Comparison with Kaersutites from Other Localities}

Kaersutite is a rather rare mineral, and so far there are only six localities of analysed kaersutite in the world. They are Kaersut, 
Greenland, the original locality of kaersutite (Lorenzen, 1886, p. 318; Gossner and Spielberger, 1930, p. 120; Drescher, 1933, p. 247): Linosa, Italy (Washington and Wright, 1908, p. 187) : Tikaisi, Dogo Island, Japan (Tomita, 1934, p. 99) : Uturyo Island, Korea (Harumoto, 1933, p. 96) : Yohodo, Korea (Kawano, 1934, p. 124): and Boulder Dam, Arizona, U.S.A. (Campbell and Schenk, 1950, p. 684). Chemical composition of these kaersutites is given in Table II for comparison. It is apparent that kaersutite has rather similar composition, and silica content varies in a narrow range from 38 to 41 per cent. Titanium content is always more than 6 per cent with exception of Boulder Dam kaersutite. Content of $\mathrm{Al}_{2} \mathrm{O}_{3}$ and of total iron vary in a reciprocal manner; i.e. high $\mathrm{Al}_{2} \mathrm{O}_{3}$ content is accompanied by low total iron content. It is interesting that the ratio of $\mathrm{FeO}$ and $\mathrm{Fe}_{2} \mathrm{O}_{3}$ varies also in a reciprocal relation. In the kaersutites from Yohodo, and from Linosa, $\mathrm{Fe}_{2} \mathrm{O}_{3}$ is more abundant than $\mathrm{FeO}$, and kaersutites from Dogo Island, Uturyo Island, and Boulder Dam have fairly high $\mathrm{Fe}_{2} \mathrm{O}_{3}$ contents, though they are less than $\mathrm{FeO}$ contents. On the other hand, kaersutites from Kaersut and Morotu have very high $\mathrm{FeO}$ contents, compared with their low $\mathrm{Fe}_{2} \mathrm{O}_{3}$ contents. In this connection, it is worthy of note that the latter two kaersutites occur in the leucocratic veins traversing mafic rocks, while kaersutites of the former group always occur in basalts, trachytes or camptonites, in which there might have been some possibility of oxidation of ferrous iron in the kaersutites. Therefore the difference in the chemical properties of the kaersutites can be ascribed to the difference in the physicochemical environment of their parent rocks.

\section{References}

Campbell, I. and Schenk, E. T.: Camptonite dikes near Boulder Dam, Arizona, Am. Min., 35, 671-692 (1950).

Drescher, F. K.: Zur Kenntnis des Peridotits von Kaersut (Grönland) und seines Ganggefolge, Tsch. Min. Pet. Mitt., 43, 207-270 (1933).

Gossner, B. and Spielberger, F.: Chemische und röntgenographisches Untersuchungen an Silikaten. Ein Beitrag zur Kenntnis der Hornblendegruppe, Zeit. Krist., 72, 111-142 (1930).

Harumoto, A.: On the kaersutite and the pigeonite found in the volcanic ejecta, Uturyo Island, Tikyu (The Globe), 19, 96-110 (1933).

Iwao, S.: Petrology of the alkaline rocks of the Nayoshi district, Sakhalin, Japan, Jap. Jour. Geol. Geogr., 16, 151-204 (1939).

Kawano, Y.: Chemical composition of kaersutite from Yohodo, Korea, Jour. Jap. Assoc. Min. Pet. Econ. Geol., 11, 124-134 (1934).

Lorenzen, J.: Untersuchungen grönlandischer Mineralien, Zeit. Krist., 11, 315-318 (1886).

Tomita, T.: On kaersutite from Dogo, Oki Islands, Japan, and its magmatic 
alteration and resorption, Jour. Shanghai Sci. Inst. Sect. 2, 1, 99-136 (1934).

Warren, B. E. : The crystal structure and chemical composition of the monoclinic amphiboles, Zeit. Krist., 72, 493-517 (1930).

Washington, H.S. and Wright, F.E.: On kaersutite from Linosa and Greenland, Am. Jour. Sci., 26, 187-221 (1908).

Yagi, K.: Petrochemical studies on the alkalic rocks of the Morotu district, Sakhalin, Bull. Geol. Soc. Am. in press (1953). 